
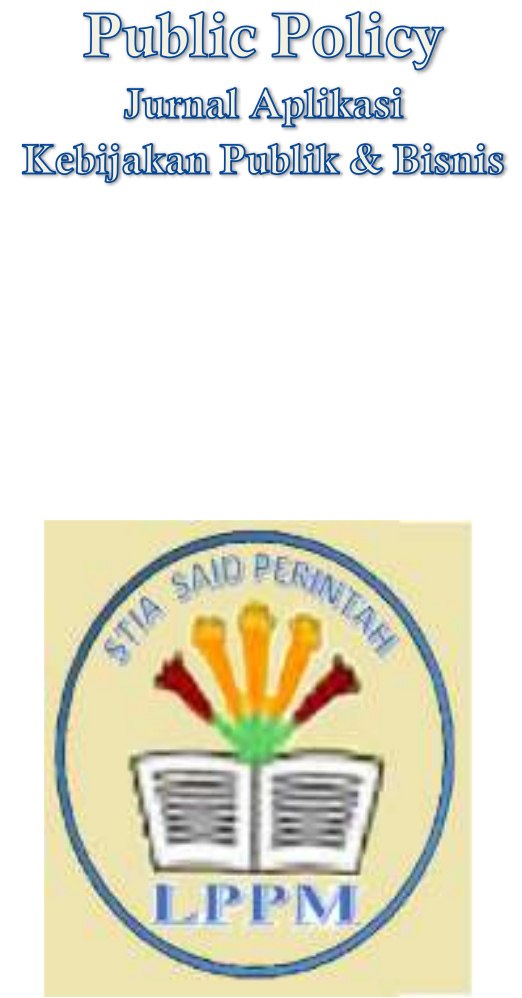

LPPM STIA Said Perintah

Volume 1, No. 2, September 2020

https://stia-saidperintah.e-journal.id/ppj

\section{Determinan Minat Kunjungan Wisata Berdasarkan Aksesibilitas, Fasilitas Pendukung Pariwisata \& Norma Subyektif} Gilbert Alvin Rumalatu

Jurusan Adm. Niaga Politeknik Negeri Ambon alvin1405@gmail.com

\begin{abstract}
The purpose of this study was to examine and analyze the impact of accessibility, tourism support facilities and subjective norms on interest in tourist visits at Ora Beach and Banda Island. The population in this study were all tourists who visited 2 tourist sites in Central Maluku Regency, namely Ora Beach and Banda Island. Based on the character inherent in the population, the sampling method used is non-probability sampling through purposive sampling technique with a final sample size of 62 tourists. Testing research data begins with testing research instruments (validity and reliability tests), testing classical assumptions followed by testing multiple linear regression analysis.

The results showed that accessibility, tourism supporting facilities and subjective norms were proven to have a positive and significant effect on the interest in tourist visits on Ora Beach and Banda Island. This can be proven through the regression coefficient of accessibility, tourism supporting facilities and subjective norms which, if an increase, will be followed by an increase in interest in tourist visits. Thus it can be said that the increase in the value of accessibility, tourism support facilities and subjective norms will encourage an increase in interest in tourist visits on Ora Beach and Banda Island.

Keywords : Accessibility, Tourism Support Facilities, Subjective Norms, Interest in Tourism Visits
\end{abstract}

\title{
Pendahuluan
}

Perkembangan industri pariwisata di Provinsi Maluku akhirnya mendapatkan angin segar, setelah berkutat panjang dengan masalah penurunan jumlah kunjungan wisatawan sejak tahun 2010. Data Kementerian Pariwisata mencatat bahwa jumlah wisatawan domestik dan mancanegara yang mengunjungi Maluku selama 2017 mengalami peningkatan sebesar 20\%. Tren positif ini terulang ditahun 2018 dan membawa dampak baik terhadap ekonomi masyarakat di Maluku maupun berdampak pada kenaikan PAD dari Dinas Pariwisata Provinsi Maluku dari tiga lokasi wisata (yakni Pantai Hunimua, Pantai 
Namalatu dan Monumen Gong Perdamaian Dunia) yang ditangani, melebihi target yang ditetapkan seperti yang disampaikan oleh Zairin Salampessy, (2019). Hasil yang menggembirakan ini terjadi karena Pemerintah Provinsi Maluku menyiapkan 23 event sepanjang 2018, dimana 2 event masuk dalam 100 Calendar of Event (CoE) Wonderful Indonesia 2018 Deandra S, n.d. (2018).

Jika ditarik ulur kebelakang maka akan terlihat bahwa Provinsi Maluku pernah merasakan "masa-masa kelam" kepariwisataan. Fakta mencatat bahwa sejak 2010, jumlah kunjungan Wisatawan ke Maluku cenderung yang mengalami penurunan, khususnya wisatawan mencanegara. Pada 2013 jumlah kunjungan hanya mencapai 3.486 orang atau turun 35.3\% disbanding tahun 2012 yang mencapai 5.389 orang. Sedangkan pada 2010 jumlah kunjungan wisatawan manca Negara sempat mencapai 8.497 orang. Sementara, jumlah Wisatawan Nusantara (Wisnus) pada 2012 terjadi kenaikan dibanding tahun 2011 sebanyak 9.537 orang. Perkembangan kunjungan Wisma dan Wisnus ke Provinsi Maluku dibanding dengan perkembangan nasional periode 2010-2013 (Kompasiana, 2014).

Penurunan jumlah kunjungan wisata di Maluku seperti yang dikutip pada (Kompasiana, 2014), disebabkan oleh barbagai faktor yang diantaranya; faktor aksesibilitas yaitu karena kondisi geografis Maluku yang berupa kepulauan menyebabkan akses menuju ke lokasi wisata menjadi sulit dan dampaknya pada biaya penyediaan akses menuju objek wisata menjadi lebih tinggi, minimnya dukungan sarana pendukung pariwisata seperti pusat informasi wisata, hotel, jumlah guide dan fasilitas kesehatan disamping tetntunya karena kurangnya dukungan anggaran pengembangan pariwisata baik yang bersumber dari DAK maupun APBD. Fakta ini sejalan dengan informasi yang dirilis (Antara, n.d.) bahwa banyak wisatawan yang membatalkan niatnya berkunjung ke objek wisata pulau Dodola karena mahalnya sewa speed boat itu, padahal salah satu objek wisata yang ingin mereka nikmati saat berkunjung ke Morotai adalah objek wisata pulau Dodola (Kabupaten Pulau Morotai, Provinsi Maluku Utara) yang terkenal keindahan itu.

Faktor-faktor penghambat inilah (aksesibilitas dan fasilitas pendukung pariwisata) yang harusnya diberikan perhatian secara khusus bukan saja oleh pemerintah daerah namun juga seluruh stakeholder sektor pariwisata yang ada di Maluku. Kajian-kajian empiris menyangkut dampak aksesibilitas terhadap minat kunjungan wisata telah banyak dilakukan, seperti yang pernah disampaikan oleh Sulfi Sulfi Abdulhaji dan Ibnu Sina Hi. Yusuf, (2016) 
yang berdasarkan hasil penelitiannya menyatakan bahwa aksessibilitas berpengaruh signifikan terhadap citra objek wisata Tolire Besar.

Peneliti lainnya, Widiyastuti, (2017) secara tersirat dapat dikatakan menyatakan hasil yang sama bahwa aksesibilitas objek wisata Umbul Ponggok sudah memenuhi dari segi akses dari jalan raya, kondisi jalan, rambu petunjuk jalan dan jarak dengan pusat Kabupaten Klaten yang secara tidak langsung memposisikan aksesibilitas sebagai kekuatan untuk mengembangkan potensi pariwisata Umbul Ponggok di Kabupaten Klaten. Halimatussaddiah Marpaung dan Hilmiatus Sahla, (2017) ditahun yang sama, menyampaikan hasil kajian yang juga sejalan bahwa aksesibilitas berpengaruh positif dan signifikan terhadap minat berkunjung wisatawan yang juga dibuktikan oleh (Widayati, 2018). Namun ternyata hasilhasil kajian empiris ini dibantah oleh Deviana, (2019) yang menyatakan hasil yang sebaiknya bahwa aksesibilitas tidak berpengaruh terhadap kepuasan wisatawan.

Selanjutnya determinan minat kunjungan wisata berdasarkan fasilitas sebenarnya bukanlah hal yang baru. Topik ini telah banyak dikaji dengan objek wisata yang berbedabeda di Indonesia. Hasil kajian empiris oleh Sulfi Abdulhaji dan Ibnu Sina Hi. Yusuf, (2016) menyatakan bahwa fasilitas berpengaruh signifikan terhadap citra objek wisata Tolire Besar. Peneliti lainnya yakni Rina Fitriani dan Setia Budhi, (2017) juga mengakui bahwa kemenarikan fasilitas berpengaruh positif terhadap minat berkunjung kembali pada Masjid Agung Jawa Tengah. Namun ternyata ada juga peneliti lain yang menyampaikan hasil kajian yang berbeda yaitu Ni Nyoman Ayu Wiratini, (2018) yang justru berhasil membuktikan bahwa fasilitas berpengaruh positif namun tidak signifikan terhadap niat kunjungan kembali wisatawan.

Faktor lain yang tidak kalah pentingnya adalah dampak aspek norma subyektif terhadap minat kunjungan wisata. Amin, (2020) menyatakan bahwa norma subjektif adalah persepsi seseorang tentang pengaruh sosial dalam membentuk perilaku tertentu, artinya tekanan sosial dapat menyebabkan perilaku seseorang bisa terpengaruh atau tidak terpengaruh. Hal ini dapat juga diartikan bahwa minat kunjungan wisata berpotensi dipengaruhi oleh tekanan social. Tekanna social dimaksud dapat bersumber dari; pengaruh interpersonal (anggota keluarga dan teman) dan pengaruh eksternal (media masa). Model pengaruh norma subyektif terhadap minat wisata juga pernah diteliti oleh Anggrein, (2009) yang membuktikan bahwa sikap dan norma subyektif berpengaruh signifikan terhadap 
minat konsumen obyek agrowisata Pagilaran. Hasil ini juga diakui oleh Amin, (2020) yang menyatakan bahwa norma subyektif terbukti berpengaruh secara positif dan signifikan terhadap minat kunjungan wisatawan di Pantai Ora (Ora Beach).

Berdasarkan pemaparan diatas maka terlihat bahwa model konseptual pengaruh aksesibilitas, fasilitas dan norma subyektif ternyata memiliki kesenjangan penelitian (research gap) khususnya pada pengaruh aksesibilitas dan fasilitas terhadap minat kunjungan wisata. Temuan inilah yang memotivasi penulis untuk mereplikasi lagi model konsetual kajian-kajian empiris diatas dengan tujuan agar dapat menganalisa pengaruh factor penghambat kenaikan jumlah kunjungan wisata tersebut (aksesibilitas dan fasilitas) serta dampak dorongan social (norma subyektif). Diharapkan melalui hasil kajian ini dapat menjadi pedoman bagi pemerintah dan stakeholder sector pariwiasata untuk tetap menjaga tren positif yang sudah ada dan juga diharapkan dapat mengurangi temuan kesenjangan penelitian yang ada. Objek wisata yang diteliti adalah destinasi wisata yang paling diminati yakni Pantai Ora dan Pulau Banda yang berlokasi di Kabupaten Maluku Tengah Provinsi Maluku.

\section{Kajian Pustaka}

\section{Minat Kunjungan Wisata}

Minat konsumen adalah keputusan konsumen mengenai preferensi atas merekmerek yang ada didalam kumpulan pilihan (Kotler dan Keler, 2009). Konsumen dapat membentuk niat untuk membeli merek yang paling disukai. Namun, ada dua faktor yang dapat berada diantara niat pembelian dan keputusan pembelian, yaitu sikap dan faktor situasi yang tidak terantisipasi Kotler Philip, (2005). Sejauh mana sikap orang lain mengurangi alternatif yang disukai seseorang akan bergantung pada dua hal, yaitu; (1) intensitas sikap negatif orang lain terhadap alternatif yang disukai konsumen, (2) motivasi konsumen untuk menuruti keinginan orang lain. Semakin gencar sikap negatif orang lain dan semakin dekat orang lain tersebut dengan konsumen, konsumen akan semakin mengubah niat pembeliannya. Keadaan sebaliknya juga berlaku preferensi pembeli terhadap merek tertentu akan meningkat jika orang yang disukai juga sangat menyukai merek yang sama (Amin, 2020). 


\section{Aksesibilitas}

Aksesibilitas adalah suatu alat yang dapat memberikan kemudahan bagi seseorang yang akan melakukan perjalanan (Widayati, 2018). Selanjutnya Soekadijo. R, (2003) menyatakan bahwa persyaratan aksesibilitas terdiri dari 3 akses yakni akses informasi dimana fasilitas mudah ditemukan dan mudah dicapai, harus memiliki akses kondisi jalan yang dapat dilalui dan sampai ke tempat wisata serta harus ada akhir dari tempat suatu perjalanan. Oleh karena itu menurut Soekadijo. R, (2003) harus selalu ada 3 aspek tersebut;

1) Akses informasi yakni menyangkut fasilitas mudah ditemukan dan mudah dicapai

2) Akses kondisi jalan menuju objek wisata, dan akses jalan tersebut harus berhubungan dengan prasarana umum.

3) Akses tempat akhir perjalanan (tempat parkir).

Hasil kajian menyangkut pengaruh aksesibilitas terhadap minat kunjungan wisata juga diadopsi dari Sulfi Abdulhaji dan Ibnu Sina Hi. Yusuf, (2016) yang berdasarkan hasil penelitiannya menyatakan bahwa aksessibilitas berpengaruh signifikan terhadap citra objek wisata Tolire Besar. Peneliti lainnya, Widiyastuti, (2017) secara tersirat dapat dikatakan menyatakan hasil yang sama bahwa aksesibilitas objek wisata Umbul Ponggok sudah memenuhi dari segi akses dari jalan raya, kondisi jalan, rambu petunjuk jalan dan jarak dengan pusat Kabupaten Klaten yang secara tidak langsung memposisikan aksesibilitas sebagai kekuatan untuk mengembangkan potensi pariwisata Umbul Ponggok di Kabupaten Klaten.

Halimatussaddiah Marpaung dan Hilmiatus Sahla, (2017) ditahun yang sama, menyampaikan hasil kajian yang juga sejalan bahwa aksesibilitas berpengaruh positif dan signifikan terhadap minat berkunjung wisatawan yang juga dibuktikan oleh (Widayati, 2018). Namun ternyata hasil-hasil kajian empiris ini dibantah oleh Sevi Mita Deviana, (2019) yang menyatakan hasil yang sebaiknya bahwa aksesibilitas tidak berpengaruh terhadap kepuasan wisatawan. Berdasarkan hasil kajian-kajian diatas maka hipotesis penelitian yang diajukan untuk diuji selanjutnya adalah;

$\mathrm{H}_{1} ;$ Aksesibilitas berpengaruh positif dan signifikan terhadap minat kunjungan wisata ke Pantai Ora dan Pulau Banda. 


\section{Fasilitas Pendukung Pariwisata}

Menurut (Sammeng, 2001 dalam Rezki Teguh Sulistiyana, (2015) bahwa salah satu hal penting untuk mengembangkan pariwisata adalah melalui fasilitas (kemudahan). Tidak jarang wisatawan berkunjung ke suatu tempat atau daerah atau negara, karena tertarik oleh kemudahan-kemudahan yang bisa diperoleh melalui fasilitas. Menurut Yoeti, (2003) dalam Rezki Teguh Sulistiyana, (2015) fasilitas wisata adalah semua fasilitas yang fungsinya memenuhi kebutuhan wisatawan yang tinggal untuk sementara waktu di daerah tujuan wisata yang dikunjunginya, dimana mereka dapat santai menikmati dan berpartisipasi dalam kegiatan yang tersedia di daerah tujuan wisata tersebut.

Hasil kajian menyangkut pengaruh aksesibilitas terhadap minat kunjungan wisata juga diadopsi dari Sulfi Abdulhaji dan Ibnu Sina Hi. Yusuf, (2016) menyatakan bahwa fasilitas berpengaruh signifikan terhadap citra objek wisata Tolire Besar. Peneliti lainnya yakni Rina Fitriani dan Setia Budhi, (2017) juga mengakui bahwa kemenarikan fasilitas berpengaruh positif terhadap minat berkunjung kembali pada Masjid Agung Jawa Tengah. Namun ternyata ada juga peneliti lain yang menyampaikan hasil kajian yang berbeda yaitu Ni Nyoman Ayu Wiratini, (2018) yang justru berhasil membuktikan bahwa fasilitas berpengaruh positif namun tidak signifikan terhadap niat kunjungan kembali wisatawan.

Berdasarkan hasil kajian-kajian diatas maka hipotesis penelitian yang diajukan untuk diuji selanjutnya adalah;

$\mathrm{H}_{2}$; Fasilitas pendukung pariwisata berpengaruh positif dan signifikan terhadap minat kunjungan wisata ke Pantai Ora dan Pulau Banda.

\section{Norma Subyektif}

Norma subyektif adalah informasi yang menganjurkan konsumen untuk mengunjungi obyek wisata (Salim, 2003). Pernyataan yang dikutip dari Sumarwan, (2003) bahwa norma subyektid selajutnya dibagi dalam 2 bagian. Pertama adalah norma (enacted norms) yang disepakati berdasarkan aturan pemerintah dan ketatanegaraan, biasanya berbentuk peraturan, undang-undang. Norma ini harus dipatuhi oleh masyarakat, dan dalam banyak hal jika normal tersebut dilanggar, akan dikenakan sanksi. Norma kedua disebut cresive norm, yaitu norma yang ada dalam budaya dan bisa dipahami dan dihayati jika orang tersebut berinteraksi dengan orang-orang dari budaya yang sama. Norma subyektif menunjukkan tekanan sosial yang dirasakan untuk melakukan atau tidak melakukan 
tindakan/perilaku seseorang dapat terpengaruh oleh pandangan orang lain atau tidak terpengaruh sama sekali. Norma subyektif dapat mempengaruhi minat (Anggrein, 2009).

Hasil kajian menyangkut pengaruh aksesibilitas terhadap minat kunjungan wisata juga diadopsi dari Anggrein, (2009) yang membuktikan bahwa sikap dan norma subyektif berpengaruh signifikan terhadap minat konsumen obyek agrowisata Pagilaran. Hasil ini juga diakui oleh Amin, (2020) yang menyatakan bahwa norma subyektif terbukti berpengaruh secara positif dan signifikan terhadap minat kunjungan wisatawan di Pantai Ora (Ora Beach). Berdasarkan hasil kajian-kajian diatas maka hipotesis penelitian yang diajukan untuk diuji selanjutnya adalah;

$\mathrm{H}_{3}$; Norma subyektif berpengaruh positif dan signifikan terhadap minat kunjungan wisata ke Pantai Ora dan Pulau Banda.

\section{Metode Penelitian}

Penelitian ini tergolong penelitian eksplanatory yang menjelaskan konsekuensi pengaruh aksesibilitas, fasilitas penunjang pariwisata dan norma subyektif terhadap minat kunjungan wisata. Pengumpulan data dilakukan dalam horizon waktu penelitian adalah studi satu tahap (one-shot study) atau cross-sectional dengan menggunakan instrumen kuesioner. Populasi dalam kajian ini adalah seluruh wisatawan yang berkunjung pada 2 lokasi wisata di Kabupaten Maluku Tengah yakni Pantai Ora dan Pulau Banda dengan jumlah yang tidak diketahui dengan pasti. Berdasarkan karakter yang melekat pada populasi tersebut maka penarikan sampel digunakan metode non probability sampling melalui teknik purposive sampling dengan jumlah sampel akhir sebanyak 62 wisatawan. Pengujian data penelitian diawali dengan pengujian instrumen penelitian (uji validitas dan reliabilitas), pengujian asumsi klasik yang dilanjutkan dengan pengujian regresi linier berganda.

Variabel yang diteliti antara lain; aksesibilitas, fasilitas pendukung pariwisata, norma subyektif dan minat kunjungan wisata. Definisi operasional aksesibilitas sendiri diadopsi dari pendapat (Widayati, 2018) yang menyebutkan aksesibilitas sebagai suatu alat yang dapat memberikan kemudahan bagi seseorang yang akan melakukan perjalanan. Definisi operasional fasilitas pendukung pariwisata dikutip dari pendapat Yoeti, (2003) dalam Rezki Teguh Sulistiyana, (2015) yang menyatakan fasilitas wisata adalah semua fasilitas yang fungsinya memenuhi kebutuhan wisatawan yang tinggal untuk sementara waktu di daerah 
tujuan wisata yang dikunjunginya. Selanjutnya, norma subyektif didefinisikan sebagai informasi yang menganjurkan konsumen untuk mengunjungi obyek wisata (Salim, 2003).

\section{Hasil dan Pembahasan}

\section{Uji Kualitas Instrumen Penelitian}

Pengujian instrument dalam penelitian ini dimaksudkan untuk menguji kesahihan atau keabsahan dari kuesioner yang digunakan peneliti (uji validitas dan reliabilitas). Pengujian validitas dalam kajian ini mengunakan korelasi Product Moment Person, dimana valid atau tidaknya instrumen dapat diketahui dengan membandingkan indeks korelasi Product Moment Person dengan signifikan 5\% (Ghozali, 2016). Sementara pengujian reliabilitas dalam kajian ini menggunakan alpha cronbachs dimana suatu instrumen dapat dikatakan reliabel jika memiliki nilai koefisien keandalan lebih besar atau sama dengan 0.6 artinya apabila $a=0.6$ maka instrumen dapat dikatakan reliabel. Hasil pengujian kualitas instrument (uji validitas dan reliabilitas) terlihat berikut ini. 
Hasil Uji Kualitas Instrumen Penelitian

\begin{tabular}{|c|c|c|c|c|c|c|}
\hline \multirow[b]{2}{*}{ Variabel } & \multicolumn{4}{|c|}{ Uji Validitas } & \multicolumn{2}{|c|}{ Uji Reliabilitas } \\
\hline & Item & $\mathbf{r}$ & Sig & Ket. & $\begin{array}{c}\text { Koefisien } \\
\text { Alpha }\end{array}$ & Ket. \\
\hline \multirow{6}{*}{$\begin{array}{c}\text { Aksesibilitas } \\
\left(\mathrm{X}_{1}\right)\end{array}$} & $\mathrm{X}_{1.1}$ & 0.713 & 0.000 & Valid & \multirow{6}{*}{0.861} & \multirow{6}{*}{ Reliabel } \\
\hline & $\overline{X_{1.2}}$ & 0.600 & 0.000 & Valid & & \\
\hline & $X_{1.3}$ & 0.666 & 0.000 & Valid & & \\
\hline & $X_{1.4}$ & 0.667 & 0.000 & Valid & & \\
\hline & $\mathrm{X}_{1.5}$ & 0.785 & 0.000 & Valid & & \\
\hline & $\mathrm{X}_{1.6}$ & 0.735 & 0.000 & Valid & & \\
\hline \multirow{6}{*}{$\begin{array}{l}\text { Fasilitas } \\
\text { Pendukung } \\
\text { Pariwisata } \\
\left(\mathrm{X}_{2}\right)\end{array}$} & $\mathrm{X}_{2.1}$ & 0.731 & 0.000 & Valid & \multirow{6}{*}{0.904} & \multirow{6}{*}{ Reliabel } \\
\hline & $\mathrm{X}_{2.2}$ & 0.721 & 0.000 & Valid & & \\
\hline & $X_{2.3}$ & 0.732 & 0.000 & Valid & & \\
\hline & $X_{2.4}$ & 0.761 & 0.000 & Valid & & \\
\hline & $X_{2.5}$ & 0.761 & 0.000 & Valid & & \\
\hline & $X_{2.6}$ & 0.746 & 0.000 & Valid & & \\
\hline \multirow{6}{*}{$\begin{array}{c}\text { Norma Subyektif } \\
\left(X_{3}\right)\end{array}$} & $X_{3.1}$ & 0.876 & 0.000 & Valid & \multirow{6}{*}{0.914} & \multirow{6}{*}{ Reliabel } \\
\hline & $\bar{X}$ & 0.855 & 0.000 & Valid & & \\
\hline & $X_{3.3}$ & 0.800 & 0.000 & Valid & & \\
\hline & $X_{3.4}$ & 0.803 & 0.000 & Valid & & \\
\hline & $X_{3.5}$ & 0.827 & 0.000 & Valid & & \\
\hline & $\mathrm{X}_{3.6}$ & 0.801 & 0.000 & Valid & & \\
\hline \multirow{6}{*}{$\begin{array}{l}\text { Minat Kunjungan } \\
\text { Wisata } \\
(\mathrm{Y})\end{array}$} & $Y_{1.1}$ & 0.644 & 0.000 & Valid & \multirow{6}{*}{0.903} & \multirow{6}{*}{ Reliabel } \\
\hline & $\mathrm{Y}_{1.2}$ & 0.660 & 0.000 & Valid & & \\
\hline & $Y_{1.3}$ & 0.702 & 0.000 & Valid & & \\
\hline & $Y_{1.4}$ & 0.742 & 0.000 & Valid & & \\
\hline & $\mathrm{Y}_{1.5}$ & 0.733 & 0.000 & Valid & & \\
\hline & $Y_{1.6}$ & 0.800 & 0.000 & Valid & & \\
\hline
\end{tabular}

Hasil dari pengujian validitas diatas menunjukan bahwa secara keseluruhan variabel penelitian ini dapat dikatakan valid karena tingkat signifikannya lebih kecil dari 0.05 dan hasil uji reliabilitas menunjukan bahwa seluruh variabel terteliti dalam kajian ini ternyata memiliki koefisien korelasi diatas 0.60 sehingga seluruh data penelitian ini dapat dikatakan realibel yang artinya data ini layak untuk dilanjutkan pada tahapan pengolahan data selanjutnya.

\section{Uji Asumsi Klasik}

\section{Uji Normalitas}

Pengujian normal tidaknya dostribusi data penelitian ini dilakukan dengan melihat peneyebaran data pada normal probability plot. Tampilan hasil pengujian normal probability plot data penelitian ini terlihat dibawah ini. 


\section{Hasil Pengujian Normalitas}

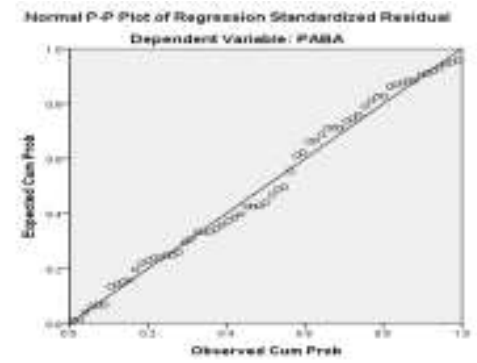

Berdasarkan normal probability plot diatas, maka data penelitian ini dapat dikatakan telah memenuhi kaidah normalitas karena terlihat bahwa data menyebar mengikuti garis diagonal, penyebarannya secara acak dan tidak membentuk pola tertentu.

\section{Uji Heterokedastisitas}

Pengujian heteroskedastisitas dalam penelitian ini dilakukan dengan melihat gambar charts scatterplot. Berikut ini adalah hasil pengujian heteroskedastisitas yang terlihat pada gambar charts scatterplot dibawah ini.

\section{Hasil Pengujian Heterokedastisitas}

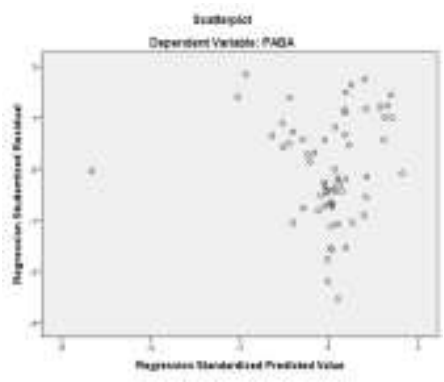

Gambar diatas menunjukan bahwa data penelitian bebas heterokedastisitas karena titiktitik data menyebar diatas dan dibawah angka 0 pada sumbu $Y$.

\section{Uji Multikoliniearitas}

Pengujian multikolinearitas kajian ini menggunakan melihat nilai Variance Inflation Faktor (VIF) atau faktor pertambahan ragam. Apabila nilai VIF lebih besar dari 10 maka terjadi multikolinieritas, sebaliknya apabila VIF lebih kecil dari 10 maka tidak terjadi multikolinieritas (Ghozali, 2016). Berikut ini adalah hasil Pengujian multikolinearitas seperti yang terlihat dibawah ini; 


\section{Pengujian Multikolinieritas}

\begin{tabular}{|c|c|c|}
\hline \multirow{2}{*}{ Variabel } & \multicolumn{2}{|c|}{ Collinearity Statistics } \\
\cline { 2 - 3 } & Tolerance & VIF \\
\hline Aksesibilitas $\left(X_{1}\right)$ & 0.130 & 7.709 \\
\hline $\begin{array}{c}\text { Fasilitas Pendukung } \\
\text { Pariwisata }\left(X_{2}\right)\end{array}$ & 0.125 & 7.969 \\
\hline Norma Subyektif $\left(X_{3}\right)$ & 0.136 & 7.367 \\
\hline
\end{tabular}

Data diatas menunjukan bahwa nilai tolerance mendekati 1 dan nilai VIF berada dibawah 10 yang berarti tidak terjadi multikolinearitas antar variabel independen dalam penelitian ini.

\section{Analisis Regresi Linier Berganda}

Alat analisis yang digunakan dalam penelitian adalah analisis regresi linier berganda dengan tujuan untuk mengetahui pengaruh pengaruh variabel independen (aksesibilitas, fasilitas pendukung pariwisata dan norma subyektif) terhadap variabel dependen (minat kunjungan wisata). Berikut ini hasil analisis regresi linier berganda yang terlihat dibawah ini.

Analisis Regresi Linier Berganda

\begin{tabular}{|c|c|c|c|c|}
\hline Variabel & $\begin{array}{l}\text { Coefficient } \\
\boldsymbol{s}\end{array}$ & $\begin{array}{c}\mathbf{t} \\
\text { hitung }\end{array}$ & Sig & Ket. \\
\hline Aksesibilitas & 0.399 & 2.488 & 0.016 & signifikan \\
\hline $\begin{array}{c}\text { Fasilitas } \\
\begin{array}{c}\text { Pendukung } \\
\text { Pariwisata }\end{array}\end{array}$ & 0.407 & 2.894 & 0.005 & signifikan \\
\hline Norma Subyektif & 0.366 & 2.178 & 0.033 & signifikan \\
\hline Adjusted R Square & 0.869 & & \\
\hline t tabel & 1.998 & \multicolumn{4}{|l}{} \\
\hline
\end{tabular}

Koefisien aksesibilitas; 0.399 menunjukkan bahwa setiap nilai aksesibilitas meningkat atau semakin baik maka nilai minat kunjungan wisata akan meningkat sebesar nilai koefisien regresi tesebut atau dengan kata lain setiap peningkatan minat kunjungan wisata dibutuhkan nilai aksesibilitas sebesar 0.399 dengan asumsi besarnya nilai fasilitas pendukung pariwisata dan norma subyektif adalah tetap. Koefisien regresi fasilitas pendukung pariwisata; 0.407 menunjukkan bahwa setiap nilai fasilitas pendukung pariwisata meningkat atau semakin baik maka nilai minat kunjungan wisata akan meningkat sebesar nilai koefisien regresi tersebut atau dengan kata lain setiap peningkatan minat 
kunjungan wisata dibutuhkan nilai fasilitas pendukung pariwisata sebesar 0.407 dengan asumsi besarnya nilai aksesibilitas dan norma subyektif adalah tetap atau konstant.

Koefisien regresi terakhir yakni, norma subyektif; 0.366 menunjukkan bahwa setiap nilai norma subyektif meningkat atau semakin baik maka nilai minat kunjungan wisata akan meningkat sebesar nilai koefisien regresi tersebut atau dengan kata lain setiap peningkatan minat kunjungan wisata dibutuhkan nilai norma subyektif sebesar 0.366 dengan asumsi besarnya nilai aksesibilitas dan fasilitas pendukung pariwisata adalah tidak berubah. Data diatas juga menunjukan bahwa model konseptual penelitian yang dibangun adalah layak karena terbukti bahwa minat kunjungan wisata di Kota Ambon mampu dijelaskan dengan baik oleh aksesibilitas, fasilitas pendukung pariwisata dan norma subyektif dengan nilai determinasi yang baik yakni sebesar 0.869 atau $86.9 \%$.

\section{Pengaruh Aksesibilitas Terhadap Minat Kunjungan Wisata}

Variabel prediktor pertama dalam kajian ini adalah aksesibilitas yang terukur melalui 6 item pernyataan. Hasil analisis inferensial menunjukan bahwa aksesibilitas menuju lokasi wisata Pantai Ora dan Pulau Banda terbukti berpengaruh positif dan signifikan terhadap minat kunjungan wisata. Hasil pengujian mengungkapkan bahwa aksesibilitas memiliki nilai $t_{\text {hitung }}$ sebesar 2.488 yang lebih besar dari nilai $t_{\text {tabel }}$ yaitu $1.998(2.488>1.998)$ yang berarti bahwa hipotesis pertama diterima. Hasil ini menunjukan bahwa aksesibilitas berpengaruh positif dan signifikan terhadap Minat kunjungan wisata di Kabupaten Pegunungan Bintang dan dapat dijustifikasi bahwa jika nilai aksesibilitas meningkat, maka peningkatan tersebut akan diikuti oleh peningkatan minat kunjungan wisata ke Pantai Ora dan Pulau Banda.

Lebih jauh dapat dijelaskan bahwa temuan terdukung oleh hasil analisis deskriptif yang menungkapkan bahwa nilai rata-rata persepsi responden tentang aksesibilitas adalah sebesar 3.99 yang berarti responden setuju dengan seluruh pernyataan tentang aksesibilitas atau secara tidak langsung dapat dikatakan bahwa aksesibilitas dipersepsikan dapat mempengaruhi minat kunjungan wisata. Hasil analisa deskriptif ini juga menunjukan bahwa indikator yang memberikan kontribusi pengaruh terbesar adalah indicator akses informasi. Artinya bahwa wisatawan ke Pantai Ora dan Pulau Banda berpersepsi bahwa kendala aksesibilitas tidak akan menjadi masalah jika informasi menyangkut fasilitas-fasilitas yang mudah ditemukan dan informasi akses paling mudah untuk menuju ke destinasi dapat terpenuhi. Temuan ini mendukung hasil kajian empiris oleh; Sulfi Abdulhaji dan Ibnu Sina 
Hi. Yusuf, (2016); Widiyastuti, (2017); Halimatussaddiah Marpaung dan Hilmiatus Sahla, (2017) dan Widayati, (2018) bahwa aksesibilitas berpengaruh terhadap minat kunjungan wisata.

\section{Pengaruh Fasilitas Pendukung Pariwisata Terhadap Minat Kunjungan Wisata}

Variabel prediktor selanjutnya adalah fasilitas pendukung pariwisata yang diukur melalui 6 item pernyataan. Hasil analisis regresi linier berganda membuktikan bahwa fasilitas pendukung pariwisata Pantai Ora dan Pulau Banda terbukti berpengaruh positif dan signifikan terhadap minat kunjungan wisata. Hasil pengujian mengungkapkan bahwa fasilitas pendukung pariwisata memiliki nilai thitung sebesar 2.894 yang lebih besar dari nilai $t_{\text {tabel }}$ yaitu $1.998(2.894>1.998)$ dengan koefisien sebesar 0.407 atau $40.7 \%$ yang berarti bahwa hipotesis kedua diterima. Hasil ini membuktikan bahwa fasilitas pendukung pariwisata berpengaruh positif dan signifikan terhadap minat kunjungan wisata ke Pantai Ora Pulau Banda dan dapat dijustifikasi bahwa jika nilai fasilitas pendukung pariwisata meningkat, maka peningkatan tersebut akan diikuti oleh peningkatan minat kunjungan wisata ke Pantai Ora dan Pulau Banda.

Hasil analisis deskriptif menunjukan bahwa mayoritas wisatawan yang berkunjung ke Pantai Ora dan Pulau Banda setuju dengan seluruh pernyataan tentang fasilitas pendukung pariwisata atau secara tidak langsung dapat dikatakan bahwa fasilitas pendukung pariwisata dipersepsikan dapat mempengaruhi minat kunjungan wisata. Hasil analisa deskriptif ini juga menunjukan bahwa indikator yang memberikan kontribusi pengaruh terbesar adalah indicator ketersediaan (kemudahan) fasilitas pada destinasi wisata. Temuan ini dapat diartikan bahwa minat kunjungan wisata akan baik jika ketersediaan (kemudahan) fasilitas pada destinasi wisata dipersepsikan baik oleh wisatawan. Temuan ini mendukung hasil penelitian sebelumnya oleh; Sulfi Abdulhaji dan Ibnu Sina Hi. Yusuf, (2016) dan yakni Rina Fitriani dan Setia Budhi, (2017) yang mengakui bahwa fasilitas berpengaruh signifikan terhadap minat kunjungan wisata.

\section{Pengaruh Norma Subyektif Terhadap Minat Kunjungan Wisata}

Variabel prediktor terakhir dalam kajian ini adalah norma subyektif yang diproksikan melalui 6 item pernyataan. Hasil analisis regresi linier berganda membuktikan bahwa norma subyektif terbukti berpengaruh positif dan signifikan terhadap minat kunjungan wisata ke Pantai Ora dan Pulau Banda. Hasil pengujian mengungkapkan bahwa norma subyektif 
memiliki nilai thitung sebesar 2.178 yang lebih besar dari nilai ttabel yaitu $1.998(2.178>1.998)$ yang artinya bahwa hipotesis terakhir ini juga diterima. Hasil ini membuktikan bahwa norma subyektif berpengaruh positif dan signifikan terhadap minat kunjungan dan dapat dijustifikasi bahwa jika nilai norma subyektif meningkat, maka peningkatan tersebut akan diikuti oleh peningkatan minat kunjungan wisata ke Pantai Ora dan Pulau Banda.

Hasil analisis deskriptif menunjukan bahwa mayoritas wisatawan yang berkunjung ke Pantai Ora dan Pulau Banda setuju dengan seluruh pernyataan tentang norma subyektif yang secara tidak langsung dapat dikatakan bahwa norma subyektif dipersepsikan dapat mempengaruhi minat kunjungan wisata. Hasil ini memberi bukti bahwa keputusan wisatawan untuk berkunjung ke Pantai Ora dan Pulau Banda juga turut dipengaruhi oleh tekanan social (dalam hal ini adalah rekomendasi keluarga atau teman dekat dan promosi melalui media). Temuan ini sejalan dengan hasil kajian empiris oleh; Anggrein, (2009) dan Amin, (2020) yang menyatakan bahwa norma subyektif terbukti berpengaruh secara positif dan signifikan terhadap minat kunjungan wisatawan.

\section{Penutup}

Berdasarkan pembahasan hasil penelitian maka kesimpulan yang dapat disampaikan adalah; minat kunjungan wisata ke Pantai Ora dan Pulau Banda dipengaruhi secara positif dan signifikan oleh aksesibilitas, fasilitas pendukung pariwisata dan norma subyektif. Rekomendasi yang dapat disampaikan bersumber dari variabel norma subyektif dengan argumen bahwa variabel ini memiliki dampak terkecil terhadap minat kunjungan wisata di Pantai Ora dan Pulau Banda. Rekomenasi dimaksud ditujukan kepada Pemerintah Daerah baik Provinsi Maluku maupun Kabupaten Maluku Tengah agar lebih menggiatkan lagi promosi destinasi wisata baik yang ada di Maluku secara keseluruhan maupun secara khusus pada Pantai Ora dan Pulau Buru sebagai upaya untuk lebih meningkatkan minat kunjungan wisatawan dimasa mendatang. Keterbatasan penelitian bahwa minat kunjungan wisata dalam kajian ini tidak menggambarkan dorongan lahirnya minat tersebut. Sehingga berdasarkan keterbatasan tersebut, direkomendasikan agar penelitian yang akan datang juga menyertakan variabel motivasi minat kungjungan wisata konsumen baik intrinsik maupun ekstrinsik. 


\section{Daftar Pustaka}

Amin, M. (2020). Model Minat Kunjungan Wisata Berdasarkan Lingkungan Fisik, Sikap dan Norma Subyektif. Public Policy (Jurnal Aplikasi Kebijakan Publik \& Bisnis), 1(1), 1-13. Retrieved from https://stia-saidperintah.e-journal.id/ppj/article/view/1/8

Anggrein, I. D. (2009). Pengaruh Sikap dan Norma Subyektif Terhadap Minat Konsumen Obyek Agrowisata Pagilaran di Kabupaten Batang. Penelitian Mandiri.

Antara. (n.d.). Wisata di Morotai Masih Terkendala Aksesibilitas. CNN Indonesia. Retrieved from https://www.cnnindonesia.com/gaya-hidup/20190506110223-269392204/wisata-di-morotai-masih-terkendala-aksesibilitas

Deandra S. (n.d.). Bidik-25.000 Wisman Maluku-Siapkan 23 Agenda Wisata 2018. Bisnis.Com. Retrieved from https://ekonomi.bisnis.com/read/20180314/12/749116/bidik-25.000-wisman-malukusiapkan-23-agenda-wisata-2018

Deviana, S. M. (2019). Pengaruh Aksesibilitas, Tarif, dan Fasilitas terhadap Kepuasan Wisatawan yang Berkunjung ke Pantai Nglambor Gunungkidul Yogyakarta (Universitas Sanata Dharma). Retrieved from https://repository.usd.ac.id/35107/

Ghozali, I. (2016). Aplikasi Analisis Multivariete Dengan Program IBM SPSS 23 (8th ed.). Semarang: Badan Penerbit Universitas Diponegoro.

Halimatussaddiah Marpaung dan Hilmiatus Sahla. (2017). Pengaruh Daya Tarik dan Aksesibilitas Terhadap Minat Berkunjung Wisatawan ke Air Terjun Ponot di Desa Tangga Kecamatan Aek Songsongan Kabupaten Asahan. , Prosiding Seminar Nasional Multidisiplin IImu UNA 2017, 1151-1160. Retrieved from https://osf.io/5h8wk/

Kompasiana. (2014, April 7). Masalah Pariwisat di Provinsi Maluku Adalah Masalah Kita Bersama. Kompasiana.Com. Retrieved from https://www.kompasiana.com/azufri/54f7ada0a3331183208b46a6/masalah-

pariwisata-di-provinsi-maluku-adalah-masalah-kita-bersama\# Kotler Philip. (2005). Manajemen Pemasaran (11th ed.). Jakarta: Erlangga.

Ni Nyoman Ayu Wiratini, N. D. S. dan N. N. Y. (2018). Analisis Faktor-Faktor yang Mempengaruhi Niat Kunjungan Kembali Wisatawan pada Daya Tarik Wisata di Kabupaten Badung. E-Jurnal Ekonomi Dan Bisnis Universitas Udayana, ス1), 279-308. Retrieved from https://ojs.unud.ac.id/index.php/EEB/article/view/34179 
Rezki Teguh Sulistiyana, D. H. dan D. F. A. (2015). Pengaruh Fasilitas Wisata dan Harga Terhadap Kepuasan Konsumen (Studi pada Museum Satwa). Jurnal Administrasi Bisnis S1 Universitas Brawijaya, 25(1), 1-9.

Rina Fitriani dan Setia Budhi. (2017). Sadar Wisata, Kemenarikan Fasilitas, Jarak, Pengaruhnya Terhadap Minat Berkunjung Kembali Pada Objek Wisata Masjid Agung Jawa Tengah di Kota Semarang. Jurnal Wawasan Manajemen, 5(3), 259-272. Retrieved from http://jwm.ulm.ac.id/id/index.php/jwm/article/view/121

Soekadijo. R. (2003). Anatomi Pariwisata. Jakarta: PT. Gramedia Pustaka.

Sulfi Abdulhaji dan Ibnu Sina Hi. Yusuf. (2016). Pengaruh Atraksi, Aksesibilitas, dan Fasilitas Terhadap Citra Objek Wisata Danau Tolire Besar di Kota Ternate. Jurnal Penelitian Humano, 72), 134-148. https://doi.org/10.16309/j.cnki.issn.1007-1776.2003.03.004 Widayati, L. N. R. dan E. (2018). Pengaruh Aksesibilitas, Amenitas, dan Atraksi Wisata Terhadap Minat Kunjungan Wisatawan ke Wahana Air Balong Waterpark Bantul Daerah Istimewa Yogyakarta. Journal of Tourism and Economic, 71$), 109-116$.

Widiyastuti, A. D. N. dan D. (2017). Kajian Atraksi, Amenitas dan Aksesibilitas untuk Pengembangan Pariwisata Umbul Ponggok di Kabupaten Klaten (pp. 6-8). pp. 6-8. https://doi.org/10.16309/j.cnki.issn.1007-1776.2003.03.004

Zairin Salampessy. (2019). PAD Sektor Pariwisata Maluku 165\% Dari Target. Gatra.Com. Retrieved from https://www.gatra.com/detail/news/378533-PAD-Sektor-PariwisataMaluku-165-Dari-Target 